\title{
Novel Tc-99m Radiotracers for Brain Imaging
}

\author{
Alessandra Boschi, Micol Pasquali, Licia Uccelli and Adriano Duatti* \\ Laboratory of Nuclear Medicine; Department of Radiological sciences; University of Ferrara; dta@ unife.it; Via L. \\ Borsari, 46, 44100 - Ferrara - Italy
}

\begin{abstract}
A novel class of Tc-99m complexes able to cross the blood brain barrier has been investigated and described here. These compounds are formed by reacting the bis-substituted nitrido precusors $\left[{ }^{99 m} T c(N)(P S)_{2}\right](P S=$ phosphinothiol ligand) with triethylborane $\left(B E t_{3}\right)$ under strictly anhydrous conditions and using non-aqueous solvents. The molecular structure of these tracers was not fully established, but preliminary experimental evidence suggests that they result from the interaction of the Lewis base $\left[{ }^{99 m} T c(N)(P S)_{2}\right]$ with the Lewis acid BEt $t_{3}$, which leads to the formation of the novel $-B-N \equiv T c$ - adduct. After purification and recovery in a physiological solution, the new boranenitrido Tc-99m derivatives were injected in rats for evaluating their in vivo biological behavior. Results showed a significant accumulation in brain tissue, thus indicating that these complexes are capable of penetrating the intact blood brain barrier. Uptake in the central nervous system was confirmed by imaging the distribution of activity on the integrated living animal using a YAP(S)SPECT small animal scanner.
\end{abstract}

Key words: Brain imaging, Nitrido complexes, Technetium-99m

\section{INTRODUCTION}

Passage of the blood brain barrier (BBB) by single molecules always constitutes a difficult challenge and this becomes even more critical when Tc-99m radiopharmaceuticals are considered. In fact, the metallic nature of the radioelement Tc-99m strongly precludes the possibility to penetrate biological membranes though passive diffusion and, thus, should be carefully shielded from the surrounding biological environment by coordination of some suitable ligand around the metal center. Despite of this, various classes of Tc-99m complexes were found to cross BBB following a concentration gradient (Johannsen \& Pietzsch, 2002; Kung, 2001), and these results clearly demonstrated the feasibility of imaging the central nervous system with Tc-99m agents.
In this study, $\operatorname{Tc}(\mathrm{V})$ nitrido complexes with phosphino-thiol ligands, $\left[{ }^{99 \mathrm{~m}} \mathrm{Tc}(\mathrm{N})(\mathrm{PS})_{2}\right]$ (PS = phosphino-thiol ligand), were used as starting substrates in a preliminary attempt to investigate the reactivity of the terminal $\mathrm{Tc} \equiv \mathrm{N}$ group toward Lewis acids like boron derivatives of the type $R_{3} B$ ( $\mathrm{R}=$ alkyl group) (Duatti et al., 2002). Biodistribution experiments in rats revealed that the resulting compounds are able to cross BBB and localize in the brain for a prolonged time. We report here the preparation and preliminary biological evaluation of this novel class of brain imaging agents.

\section{MATERIAL AND METHODS}

Technetium-99m was eluted from a ${ }^{99} \mathrm{Mo} /{ }^{99 m} \mathrm{Tc}$ generator provided by Amersham Sorin (Saluggia, Italy). The phosphino-thiol ligands, 2-

* Author for correspondence 
(dipropylphosphino)ethanethiolate

and 2(diisopropylphosphino)ethanethiolate, (Fig. 1) were purchased from Argus Chemicals (Florence, Italy). Solutions of triethylborane $\left(\mathrm{BEt}_{3}, 1.0 \mathrm{M}\right.$ in THF) can be purchased from Aldrich (Milan, Italy) or, alternatively, be prepared by dissolving the equivalent amount of $\mathrm{BEt}_{3}$ (98\%, Strem Chemicals, Caution: highly pyrophoric) in anhydrous THF (99.9\% inhibited with 250 ppm BHT, Aldrich). All other commercially available compounds and common solvents were reagent grade, and were used without further purification.
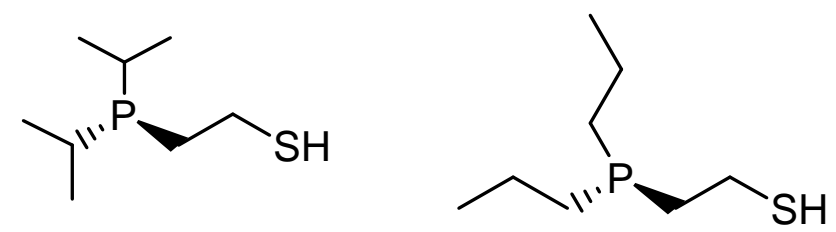

Figure 1 - The phosphino-thiol ligands utilized in this study

\section{$\left[{ }^{99 m} \operatorname{Tc}(N)(P S)_{2}\right]$}

The procedure for the preparation of these type of complexes has been described previously (Bolzati et al., 1999). Briefly, $0.50 \mathrm{ml}$ of saline containing [ $\left.{ }^{99 \mathrm{~m}} \mathrm{TcO}_{4}\right]^{-}$(approximately, $50 \mathrm{mCi}$ ) were added to a lyophilized vial containing $0.1 \mathrm{mg}$ of $\mathrm{SnCl}_{2}, 5.0$ $\mathrm{mg}$ of succinic dihydrazide (SDH) and $5.0 \mathrm{mg}$ of diethylenetriaminopentaacetic acid (DTPA). The resulting solution was kept at room temperature for 30 minutes. The $\mathrm{pH}$ of the solution was raised to 8.0 by addition of $0.25 \mathrm{ml}$ of a $\mathrm{HCO}_{3}{ }^{-} / \mathrm{CO}_{3}{ }^{2-}$ buffer $(0.5 \mathrm{M})$. Then, $0.10 \mathrm{ml}$ of an ethanolic solution of the appropriate PSH ligand were added, and the reaction vial was heated at $100{ }^{\circ} \mathrm{C}$ for 15 30 minutes. (Yield $>90 \%$ ).

\section{$\left.{ }^{99 m} \mathrm{Tc}\left(\mathrm{NBEt}_{3}\right)(\mathrm{PS})_{2}\right]$}

The appropriate starting complex $\left[{ }^{99 \mathrm{~m}} \mathrm{Tc}(\mathrm{N})(\mathrm{PS})_{2}\right]$ $\left\{\mathrm{PS}=\left[\left(\mathrm{CH}_{3}\right)_{2} \mathrm{CH}\right]_{2}-\mathrm{P}\left(\mathrm{CH}_{2}\right)_{2}-\mathrm{SH}\right.$ and $\left[\mathrm{CH}_{3}(\mathrm{CH})_{2}\right]_{2}-$ $\left.\mathrm{P}\left(\mathrm{CH}_{2}\right)_{2}-\mathrm{SH}\right\}$ was prepared according to the procedure outlined above. Due to the pyrophoric nature of the compound $\mathrm{BEt}_{3}$, all operations with this material were conducted in a glove-box under a pressure-controlled argon atmosphere (UniLab, MBraun). A reversed phase C18 cartridge (SepPak, Waters) was activated by first passing $5.0 \mathrm{ml}$ of $95-\%$ ethanol, followed by $5.0 \mathrm{ml}$ of deionized water. The reaction solution of the complex $\left[{ }^{99 \mathrm{~m}} \mathrm{Tc}(\mathrm{N})(\mathrm{PS})_{2}\right]$ was diluted by addition of $9.0 \mathrm{ml}$ of deionized water. The resulting solution was then passed through the activated SepPak cartridge. Approximately, 70-80\% of the initial activity into the reaction vial was retained onto the cartridge. After rinsing the cartridge with deionized water $(10.0 \mathrm{ml})$, and $25-\%$ ethanol $(10.0 \mathrm{ml})$, the complex was recovered by passing absolute ethanol $(4 \times 0.50 \mathrm{ml})$. Approximately, $60-70 \%$ of the activity onto the cartridge was collected in the second fraction. The ethanolic solution containing the complex $\left[{ }^{99 \mathrm{~m}} \mathrm{Tc}(\mathrm{N})(\mathrm{PS})_{2}\right](0.50 \mathrm{ml})$ was placed inside the glove-box and purged with argon for 10 minutes (if necessary, the loss of the solvent was reconstituted with anhydrous THF). $1.0 \mathrm{ml}$ of the THF solution of $\mathrm{BEt}_{3}$ was then introduced using a glass needle, and the reaction vial was sealed and heated at $80{ }^{\circ} \mathrm{C}$ in a heating block for 1 hour. (Yield in the range 10-40\%). For biodistribution studies, the resulting product was isolated by HPLC purification (see HPLC conditions below) and then passed through a C18 cartridge using the same procedure described above.

\section{Chromatography}

Chromatographic analysis was performed on a Beckman System Gold HPLC instrument using a Waters Symmetry Shield C18 column and the following gradient. $\mathrm{A}=\left[\mathrm{NH}_{4}\right]\left[\mathrm{CH}_{3} \mathrm{CO}_{2}\right](0.01 \mathrm{~mol}$ $\left.\mathrm{dm}^{-1}, \mathrm{pH}=5\right), \mathrm{B}=\mathrm{CH}_{3} \mathrm{CN} ; 0-20 \min , \mathrm{B}=60 \%$; $20-40 \mathrm{~min}, \mathrm{~B}=100 \%$; 40-45 $\mathrm{min}, \mathrm{B}=60 \%$. TLC chromatography was performed on both silica-gel and reversed-phase C18 plates (Merck). Chromatographic data of some representative complexes are reported in Table 1 .

\section{Serum stability}

After HPLC purification, $100 \mu \mathrm{L}$ of the selected Tc-99m complex were added to a propylene test tube $(5 \mathrm{ml})$ containing $900 \mu \mathrm{L}$ of rat serum or, alternatively, $900 \mu \mathrm{L}$ of saline. The resulting mixture was incubated at $37{ }^{\circ} \mathrm{C}$ for 2 hours. RCP changes in time were checked at $15,30,60$, and 120 min by TLC. 
In vitro reaction with glutathione (GSH) and cysteine

A phosphate buffer $\left(250 \mu \mathrm{L}, 0.2 \mathrm{~mol} / \mathrm{dm}^{3}, \mathrm{pH}=\right.$ 7.4), water $(100 \mu \mathrm{L})$, the appropriate HPLCpurified Tc-99m complex $(100 \mu \mathrm{L})$ and an aliquot $(50 \mu \mathrm{L})$ of a stock aqueous solution of GSH $(0.01$ mol dm${ }^{-3}$ ) were mixed in a propylene test tube $(5$ $\mathrm{ml}$ ), and the mixture was incubated at $37{ }^{\circ} \mathrm{C}$ for 2 hours. For the blank experiment, an equal volume of water was added in place of the GSH solution. Aliquots of the resulting solutions were withdrawn at 15, 30,60 and $120 \mathrm{~min}$ after incubation, and analyzed by TLC chromatography.

The same procedure applied above for GSH challenge was performed in two separate experiments using two different aqueous solutions of cysteine hydrochloride $\left(0.01\right.$ and $0.001 \mathrm{~mol} / \mathrm{dm}^{3}$, respectively).

\section{Biodistribution Studies}

All animal experiments were performed using purified fractions of the selected complex obtained by HPLC separation. Before injection, the collected activity was loaded onto a C18 SepPak cartridge previously activated with $5 \mathrm{ml}$ of $\mathrm{EtOH}$ and $5.0 \mathrm{ml}$ of water. The cartridge was washed with $20.0 \mathrm{ml}$ of water followed by $0.5 \mathrm{ml}$ of a mixture of $\mathrm{EtOH}$ and water (80:20). Most of the adsorbed activity (90\%) was recovered by passing $1.0 \mathrm{ml}$ of EtOH and further diluted with PBS $\left(0.1 \mathrm{~mol} \mathrm{dm}^{-3}\right.$, $\mathrm{pH}, 7.4)$ to give a final solution that was $10 \%$ in EtOH content. Female Sprague-Dawley rats weighing 200-250 g were anesthetized with an intramuscle injection of a mixture of ketamine (80 $\mathrm{mg} / \mathrm{kg}$ ) and xilazine $(19 \mathrm{mg} / \mathrm{kg})$. A jugular vein was surgically exposed, and $100 \mu \mathrm{L}$ (300-370 $\mathrm{kBq}$ ) of the solution containing the radioactive complex were injected. The animals $(n=3)$ were sacrificed by cervical dislocation at different times post injection. The blood was withdrawn from the heart through a syringe immediately after the sacrifice and counted. Harvested organs were rinsed in saline, weighed and counted in a $\gamma$-counter. Results expressed as $\% \mathrm{ID} / \mathrm{g}$ tissue are reported in the Tables 2 to 5 .

\section{Animal Imaging}

Images of the biodistribution of the hypothetical complex $\left[{ }^{99 \mathrm{~m}} \mathrm{Tc}\left(\mathrm{NBEt}_{3}\right)(\mathrm{PS})_{2}\right]\left\{\mathrm{PS}=\left[\left(\mathrm{CH}_{3}\right)_{2} \mathrm{CH}\right]_{2^{-}}\right.$ $\left.\mathrm{P}\left(\mathrm{CH}_{2}\right)_{2}-\mathrm{SH}\right\}$ in rats were obtained with a YAP(S)PET small-animal scanner (Di Domenico et al., 2003; Humm et al., 2003) after injection of $1.0 \mathrm{mCi}$ of activity in the jugular vein as described elsewhere (Boschi et al., 2003). Fig. 4 illustrates the biodistribution registered at 1.0 hour after tracer administration.

\section{RESULTS AND DISCUSSION}

The symmetrical, bis-substituted nitrido $\mathrm{Tc}(\mathrm{V})$ complexes with phosphino-thiol ligands have been prepared and their biodistributions evaluated in rats. Preparation of these complexes was carried out following standard procedures for preparing Tc-99m radiopharmaceuticals containing a terminal $\mathrm{Tc} \equiv \mathrm{N}$ multiple bond (Boschi et al., 2005). Briefly, $\left[{ }^{99 \mathrm{~m}} \mathrm{TcO}_{4}\right]^{-}$was reacted with succinic dihydrazide and $\mathrm{SnCl}_{2}$ to form a mixture of intermediate complexes containing the $\left[{ }^{99 \mathrm{~m}} \mathrm{Tc} \equiv \mathrm{N}\right]^{2+}$ group. These precursors were then reacted with the appropriate PSH ligand to afford the final bissubstituted complexes $\left[{ }^{99 \mathrm{~m}} \mathrm{Tc}(\mathrm{N})(\mathrm{PS})_{2}\right]$. The chemical structure of the resulting complexes is illustrated in Fig. 2.

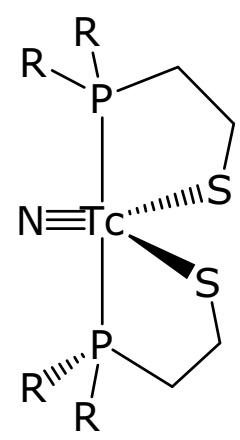

Figure 2 - The chemical structure of the complexes $\left[{ }^{99 \mathrm{~m}} \mathrm{Tc}(\mathrm{N})(\mathrm{PS})_{2}\right]$ 
The complexes $\left[{ }^{99 \mathrm{~m}} \mathrm{Tc}(\mathrm{N})(\mathrm{PS})_{2}\right]$ possess a trigonal bipyramidal structure where two PS ligands are coordinated through the $\mathrm{P}$ and $\mathrm{S}$ atoms, the remaining coordination position being spanned by the $\mathrm{T} c \equiv \mathrm{N}$ group. As predicted, the two $\pi$-acceptor atoms occupy the axial positions, and the three $\pi$ donor atoms are positioned on the trigonal plane.

Biodistributions in rats are reported in the Tables 1 and 2. A significant brain localization was observed only for the complex with the ligand
$\left[\left(\mathrm{CH}_{3}\right)_{2} \mathrm{CH}\right]_{2}-\mathrm{P}\left(\mathrm{CH}_{2}\right)_{2}-\mathrm{SH}$. Peak activity in the brain occurred at 2 min post injection, and was then followed by a fast washout. It was found that heart was a target organ for all complexes, though activity was rapidly washed out after $10 \mathrm{~min}$ post injection. The main elimination route took place through the liver.

Table 1 - Chromatographic data of Tc-99m complexes

\begin{tabular}{lcc}
\hline Complex & $\begin{array}{c}\text { HPLC } \\
\text { Retention time (min) }\end{array}$ & $\begin{array}{c}\text { TLC }^{\mathbf{a}} \\
\mathbf{R}_{\mathbf{f}}\end{array}$ \\
\hline$\left[{ }^{99 \mathrm{~m}} \mathrm{Tc}(\mathrm{N})(\mathrm{PS})_{2}\right]\left\{\mathrm{PS}=\left[\left(\mathrm{CH}_{3}\right)_{2} \mathrm{CH}\right]_{2} \mathrm{P}\left(\mathrm{CH}_{2}\right)_{2} \mathrm{~S}\right\}$ & 19.2 & 0.40 \\
{$\left[{ }^{99 \mathrm{~m}} \mathrm{Tc}(\mathrm{N})(\mathrm{PS})_{2}\right]\left\{\mathrm{PS}=\left[\mathrm{CH}_{3}\left(\mathrm{CH}_{2}\right)_{2}\right]_{2} \mathrm{P}\left(\mathrm{CH}_{2}\right)_{2} \mathrm{~S}\right\}$} & 17.4 & 0.30 \\
{$\left[{ }^{99 \mathrm{~m}} \mathrm{Tc}(\mathrm{PS})_{2}\left(\mathrm{C}_{6} \mathrm{H}_{5} \mathrm{~S}\right)\right]\left\{\mathrm{PS}=\left[\left(\mathrm{CH}_{3}\right)_{2} \mathrm{CHCH}_{2}\right]_{2}-\mathrm{P}\left(\mathrm{CH}_{2}\right)_{2} \mathrm{~S}\right\}$} & 32.2 & 0.72 \\
{$\left[{ }^{99 \mathrm{~m}} \mathrm{Tc}\left(\mathrm{NBEt}_{3}\right)(\mathrm{PS})_{2}\right]\left\{\mathrm{PS}=\left[\mathrm{CH}_{3}\left(\mathrm{CH}_{2}\right)_{2}\right]_{2}-\mathrm{P}\left(\mathrm{CH}_{2}\right)_{2} \mathrm{~S}\right\}$} & 13.5 & 0.56 \\
$\left.{ }^{99 \mathrm{~m}} \mathrm{Tc}(\mathrm{NBEt})(\mathrm{PS})_{2}\right]\left\{\mathrm{PS}=\left[\left(\mathrm{CH}_{3}\right)_{2} \mathrm{CH}\right]_{2}-\mathrm{P}\left(\mathrm{CH}_{2}\right)_{2} \mathrm{~S}\right\}$ & 12.1 & 0.52 \\
\hline${ }^{a} \mathrm{Si}$ & &
\end{tabular}

${ }^{a)} \mathrm{SiO}_{2}$; Mobile phase: EtOH/CHCl $3 /$ Toluene/[ $\left.\mathrm{NH}_{4}\right]\left[\mathrm{CH}_{2} \mathrm{CO}_{2}\right]$ (5:6:6:0.5)

Table 2 - Biodistribution in rats of the complex $\left[{ }^{99 \mathrm{~m}} \mathrm{Tc}(\mathrm{N})(\mathrm{PS})_{2}\right]\left\{\mathrm{PS}=\left[\left(\mathrm{CH}_{3}\right)_{2} \mathrm{CH}\right]_{2}-\mathrm{P}\left(\mathrm{CH}_{2}\right)_{2} \mathrm{~S}\right\}$

\begin{tabular}{lcccc}
\hline Organ & $\mathbf{2} \mathbf{~ m i n}$ & $\mathbf{1 0} \mathbf{~ m i n}$ & $\mathbf{2 0} \mathbf{~ m i n}$ & $\mathbf{6 0} \mathbf{~ m i n}$ \\
\hline Blood & $0.32 \pm 0.04$ & $0.24 \pm 0.01$ & $0.23 \pm 0.01$ & $0.16 \pm 0.01$ \\
Brain & $1.38 \pm 0.09$ & $0.97 \pm 0.18$ & $0.08 \pm 0.01$ & $0.03 \pm 0.00$ \\
Heart & $2.45 \pm 0.39$ & $0.37 \pm 0.05$ & $0.28 \pm 0.04$ & $0.16 \pm 0.01$ \\
Lungs & $0.90 \pm 0.13$ & $0.39 \pm 0.02$ & $0.35 \pm 0.06$ & $0.23 \pm 0.02$ \\
Liver & $2.95 \pm 0.40$ & $2.18 \pm 0.32$ & $1.81 \pm 0.30$ & $0.99 \pm 0.03$ \\
Spleen & $1.14 \pm 0.20$ & $2.27 \pm 0.03$ & $0.20 \pm 0.02$ & $0.14 \pm 0.01$ \\
Kidneys & $1.56 \pm 0.42$ & $0.71 \pm 0.05$ & $0.56 \pm 0.13$ & $0.36 \pm 0.04$ \\
Intestine & $2.48 \pm 0.50$ & $7.15 \pm 0.96$ & $13.7 \pm 6.10$ & $8.56 \pm 1.80$ \\
Muscle & $0.17 \pm 0.05$ & $0.17 \pm 0.02$ & $0.25 \pm 0.05$ & $1.14 \pm 0.02$ \\
\hline
\end{tabular}

(\%dose/g, $n=3$ )

The compounds $\quad\left[{ }^{99 \mathrm{~m}} \mathrm{Tc}(\mathrm{N})(\mathrm{PS})_{2}\right] \quad\{\mathrm{PS} \quad=\quad$ in anhydrous THF solution to form a novel class of $\left[\left(\mathrm{CH}_{3}\right)_{2} \mathrm{CH}\right]_{2}-\mathrm{P}\left(\mathrm{CH}_{2}\right)_{2}-\mathrm{SH}$ and $\left[\mathrm{CH}_{3}(\mathrm{CH})_{2}\right]_{2^{-}}$complexes that, tentatively, were assumed to pos$\mathrm{P}\left(\mathrm{CH}_{2}\right)_{2}-\mathrm{SH}$ \} were successively reacted with $\mathrm{BEt}_{3}$ sess the composition [ $\left.{ }^{99 \mathrm{~m}} \mathrm{Tc}\left(\mathrm{NBEt}_{3}\right)(\mathrm{PS})_{2}\right]$. The 
hypothetical chemical structure of these complexes

is pictured in Fig. 3.

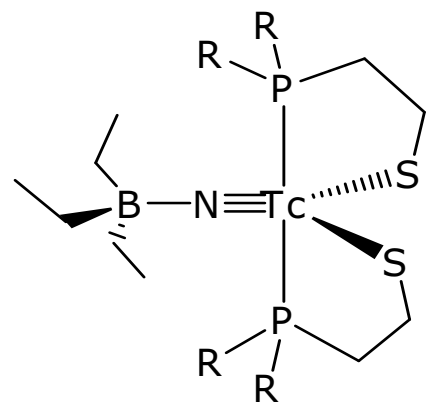

Figure 3 - Proposed chemical structure of the complexes [ $\left.{ }^{99 \mathrm{~m}} \mathrm{Tc}\left(\mathrm{NBEt}_{3}\right)(\mathrm{PS})_{2}\right]$

Table 3 - Biodistribution in rats of the complex $\left[{ }^{99 \mathrm{~m}} \mathrm{Tc}(\mathrm{N})(\mathrm{PS})_{2}\right]\left\{\mathrm{PS}=\left[\mathrm{CH}_{3}\left(\mathrm{CH}_{2}\right)_{2}\right]_{2}-\mathrm{P}\left(\mathrm{CH}_{2}\right)_{2} \mathrm{~S}\right\}$

\begin{tabular}{lcccc}
\hline Organ & $\mathbf{2}$ $\mathbf{m}$ & $\mathbf{1 0} \mathbf{~}$ in & $\mathbf{2 0} \mathbf{~ m i n}$ & $\mathbf{6 0 ~} \mathbf{\text { in }}$ \\
\hline Blood & $1.67 \pm 0.54$ & $0.94 \pm 0.13$ & $0.52 \pm 0.02$ & $0.18 \pm 0.01$ \\
Brain & $0.76 \pm 0.09$ & $0.12 \pm 0.05$ & $0.04 \pm 0.01$ & $0.02 \pm 0.00$ \\
Heart & $2.16 \pm 0.17$ & $0.88 \pm 0.11$ & $0.49 \pm 0.04$ & $0.19 \pm 0.01$ \\
Lungs & $1.02 \pm 0.66$ & $0.51 \pm 0.08$ & $0.43 \pm 0.02$ & $0.86 \pm 0.04$ \\
Liver & $1.53 \pm 0.21$ & $1.48 \pm 0.16$ & $2.06 \pm 0.39$ & $0.92 \pm 0.12$ \\
Spleen & $2.40 \pm 0.33$ & $1.61 \pm 0.04$ & $1.15 \pm 0.10$ & $0.81 \pm 0.04$ \\
Kidneys & $1.47 \pm 0.12$ & $1.31 \pm 0.06$ & $1.39 \pm 0.14$ & $1.03 \pm 0.09$ \\
Intestine & $2.68 \pm 0.07$ & $5.15 \pm 1.24$ & $10.6 \pm 1.18$ & $9.89 \pm 0.45$ \\
Muscle & $0.11 \pm 0.03$ & $0.15 \pm 0.01$ & $0.20 \pm 0.02$ & $0.20 \pm 0.01$ \\
\hline
\end{tabular}

(\%dose/g, $n=3)$

The preparation of these new derivatives was rather complex. After formation, the bissubstituted compounds $\left[{ }^{99 \mathrm{~m}} \mathrm{Tc}(\mathrm{N})(\mathrm{PS})_{2}\right]$ were charged onto a reversed-phase C18 cartridge, and then recovered by passing ethanol. The resulting solution was treated with excess of $\mathrm{BEt}_{3}$ in anhydrous THF and heated at $80{ }^{\circ} \mathrm{C}$ for 1 hour in a heating block. HPLC analysis of the reaction products showed the presence of two wellresolved peaks. One peak was identified with the initial bis-substituted complex $\left[{ }^{99 \mathrm{~m}} \mathrm{Tc}(\mathrm{N})(\mathrm{PS})_{2}\right]$, the remaining peak being associated with an unprecedented compound. At present, no macroscopic synthesis with the long-lived isotope Tc-99m has been carried out in the attempt to elucidate the chemical nature of the new complexes. A possible structure is as showed in Fig. 3, and it can be thought of as resulting from an acid-base reaction between the Lewis acid $\mathrm{BEt}_{3}$ and the Lewis base $\mathrm{Tc} \equiv \mathrm{N}$. This formulation is mostly supported by results obtained in exchange reactions with diethyldithiocarbamate, $\left(\mathrm{CH}_{3} \mathrm{CH}_{2}\right)_{2}-\mathrm{N}-\mathrm{CS}_{2}{ }^{-}$(DEDC), where the nitrido-borane complexes were easily converted into the bis-substituted dithiocarbamato nitrido complexes $\left[{ }^{99 \mathrm{~m}} \mathrm{Tc}(\mathrm{N})(\mathrm{DEDC})_{2}\right]$, thus suggesting that the Tc-99m nitrido core is recovered unaltered when the surrounding ligands are changed from mixed $\pi$-donor $/ \pi$-acceptor phosphino-thiol ligands to $\pi$-donor dithiocarbamato ligands. The overall yield of formation of the 
complexes $\left[{ }^{99 \mathrm{~m}} \mathrm{Tc}\left(\mathrm{NBEt}_{3}\right)(\mathrm{PS})_{2}\right]$ was lower than $40 \%$.

Table 4 - Biodistribution in rats of the complex $\left[{ }^{99 m} \mathrm{Tc}\left(\mathrm{NBEt}_{3}\right)(\mathrm{PS})_{2}\right]\left\{\mathrm{PS}=\left[\mathrm{CH}_{3}\left(\mathrm{CH}_{2}\right)_{2}\right]_{2} \mathrm{P}\left(\mathrm{CH}_{2}\right)_{2} \mathrm{~S}\right\}$

\begin{tabular}{lcccccc}
\hline Organ & $\mathbf{0 ~} \mathbf{~ m i n}$ & $\mathbf{2} \mathbf{~ m i n}$ & $\mathbf{1 0} \mathbf{~ m i n}$ & $\mathbf{2 0} \mathbf{~ m i n}$ & $\mathbf{3 0} \mathbf{~}$ in & $\mathbf{6 0} \mathbf{~ m i n}$ \\
\hline Blood & $0.86 \pm 0.08$ & $0.60 \pm 0.07$ & $0.24 \pm 0.01$ & $0.17 \pm 0.02$ & $0.20 \pm 0.03$ & $0.10 \pm 0.01$ \\
Brain & $4.75 \pm 0.15$ & $4.68 \pm 0.12$ & $4.27 \pm 0.08$ & $3.94 \pm 0.26$ & $3.86 \pm 0.13$ & $3.80 \pm 0.10$ \\
Heart & $0.26 \pm 0.02$ & $0.10 \pm 0.06$ & $0.60 \pm 0.04$ & $0.25 \pm 0.01$ & $0.16 \pm 0.01$ & $0.09 \pm 0.00$ \\
Lungs & $1.06 \pm 0.05$ & $0.78 \pm 0.07$ & $0.22 \pm 0.00$ & $0.23 \pm 0.01$ & $0.07 \pm 0.00$ & $0.09 \pm 0.02$ \\
Liver & $1.76 \pm 0.14$ & $2.93 \pm 0.24$ & $1.04 \pm 0.18$ & $0.77 \pm 0.70$ & $0.81 \pm 0.08$ & $0.27 \pm 0.03$ \\
Spleen & $0.75 \pm 0.16$ & $1.04 \pm 0.01$ & $0.57 \pm 0.03$ & $0.47 \pm 0.11$ & $0.52 \pm 0.01$ & $0.28 \pm 0.03$ \\
Kidneys & $3.96 \pm 0.13$ & $10.9 \pm 0.13$ & $17.9 \pm 0.60$ & $11.8 \pm 0.25$ & $8.62 \pm 0.03$ & $4.38 \pm 0.08$ \\
Intestine & $1.56 \pm 0.12$ & $2.23 \pm 1.13$ & $3.39 \pm 0.43$ & $1.67 \pm 0.13$ & $1.73 \pm 0.22$ & $1.40 \pm 0.73$ \\
Muscle & $0.20 \pm 0.03$ & $0.18 \pm 0.02$ & $0.16 \pm 0.02$ & $0.20 \pm 0.02$ & $0.11 \pm 0.03$ & $0.10 \pm 0.01$ \\
\hline \%dose/g, $n=3)$ & & & & & &
\end{tabular}

The compounds [ $\left.{ }^{99 \mathrm{~m}} \mathrm{Tc}\left(\mathrm{NBEt}_{3}\right)(\mathrm{PS})_{2}\right]$ were isolated by HPLC. The collected activity was passed through a reversed-phase $\mathrm{C} 18$ cartridge and then recovered with ethanol. The resulting solution was diluted with saline to obtain a solution suitable for injection in rats. Surprisingly, biodistribution results showed that these complexes accumulated into the brain to a remarkable extent, and activity was retained in this region for a prolonged time. The most interesting result comes from the observation that incorporation of $\mathrm{BEt}_{3}$ into the chemical structure of the starting [ $\left.{ }^{99 \mathrm{~m}} \mathrm{Tc}(\mathrm{N})(\mathrm{PS})_{2}\right]$ complexes greatly improves their brain localization. In particular, it is important to emphasize that although the complex $\left[{ }^{99 \mathrm{~m}} \mathrm{Tc}(\mathrm{N})(\mathrm{PS})_{2}\right]$ where $\mathrm{PS}=$ $\left[\mathrm{CH}_{3}(\mathrm{CH})_{2}\right]_{2}-\mathrm{P}\left(\mathrm{CH}_{2}\right)_{2}-\mathrm{SH}$, did not show any significant brain uptake, approximately $4 \%$ of the injected activity of the supposed tris-ethyl borane derivative $\left[{ }^{99 \mathrm{~m}} \mathrm{Tc}\left(\mathrm{NBEt}_{3}\right)(\mathrm{PS})_{2}\right]$ was taken up by the brain after 2 min post injection. Brain washout was slow and after 60 min post injection about $50 \%$ of the initial activity was still retained in the cerebral region. Blood clearance was fast and elimination occurred mostly through the liver and kidneys. Fig. 4 illustrates the biodistribution registered at 1.0 hour after tracer administration with a small-animal YAP(S) PET tomograph.

Table 5 - Biodistribution in rats of the complex $\left[{ }^{99 \mathrm{~m}} \mathrm{Tc}\left(\mathrm{NBEt}_{3}\right)(\mathrm{PS})_{2}\right]\left\{\mathrm{PS}=\left[\left(\mathrm{CH}_{3}\right)_{2} \mathrm{CH}\right]_{2}-\mathrm{P}\left(\mathrm{CH}_{2}\right)_{2} \mathrm{~S}\right\}$

\begin{tabular}{|c|c|c|c|c|c|c|}
\hline Organ & 0 min & $2 \mathrm{~min}$ & $10 \mathrm{~min}$ & $20 \mathrm{~min}$ & $30 \mathrm{~min}$ & $60 \mathrm{~min}$ \\
\hline Blood & $0.98 \pm 0.07$ & $1.01 \pm 0.09$ & $0.68 \pm 0.00$ & $0.26 \pm 0.03$ & $0.21 \pm 0.01$ & $0.09 \pm 0.00$ \\
\hline Brain & $4.18 \pm 0.21$ & $4.06 \pm 0.14$ & $4.03 \pm 0.36$ & $3.83 \pm 0.10$ & $3.12 \pm 0.45$ & $3.01 \pm 0.21$ \\
\hline Heart & $0.83 \pm 0.05$ & $0.56 \pm 0.01$ & $0.34 \pm 0.01$ & $0.30 \pm 0.01$ & $0.25 \pm 0.02$ & $0.14 \pm 0.00$ \\
\hline Lungs & $1.63 \pm 0.20$ & $1.01 \pm 0.09$ & $0.53 \pm 0.01$ & $0.46 \pm 0.01$ & $0.34 \pm 0.02$ & $0.18 \pm 0.00$ \\
\hline Liver & $2.08 \pm 0.05$ & $2.09 \pm 0.06$ & $1.37 \pm 0.14$ & $1.88 \pm 0.14$ & $0.93 \pm 0.01$ & $0.40 \pm 0.03$ \\
\hline Spleen & $0.86 \pm 0.10$ & $0.55 \pm 0.06$ & $0.46 \pm 0.01$ & $0.33 \pm 0.01$ & $0.28 \pm 0.06$ & $0.19 \pm 0.01$ \\
\hline Kidneys & $5.23 \pm 0.31$ & $9.54 \pm 0.75$ & $15.4 \pm 0.60$ & $14.6 \pm 0.34$ & $8.44 \pm 0.22$ & $4.72 \pm 0.36$ \\
\hline Intestine & $0.77 \pm 0.11$ & $1.48 \pm 0.14$ & $3.03 \pm 0.93$ & $3.01 \pm 0.32$ & $2.14 \pm 0.28$ & $1.11 \pm 0.60$ \\
\hline Muscle & $0.16 \pm 0.01$ & $0.21 \pm 0.01$ & $0.19 \pm 0.02$ & $0.17 \pm 0.01$ & $0.13 \pm 0.01$ & $0.12 \pm 0.00$ \\
\hline
\end{tabular}




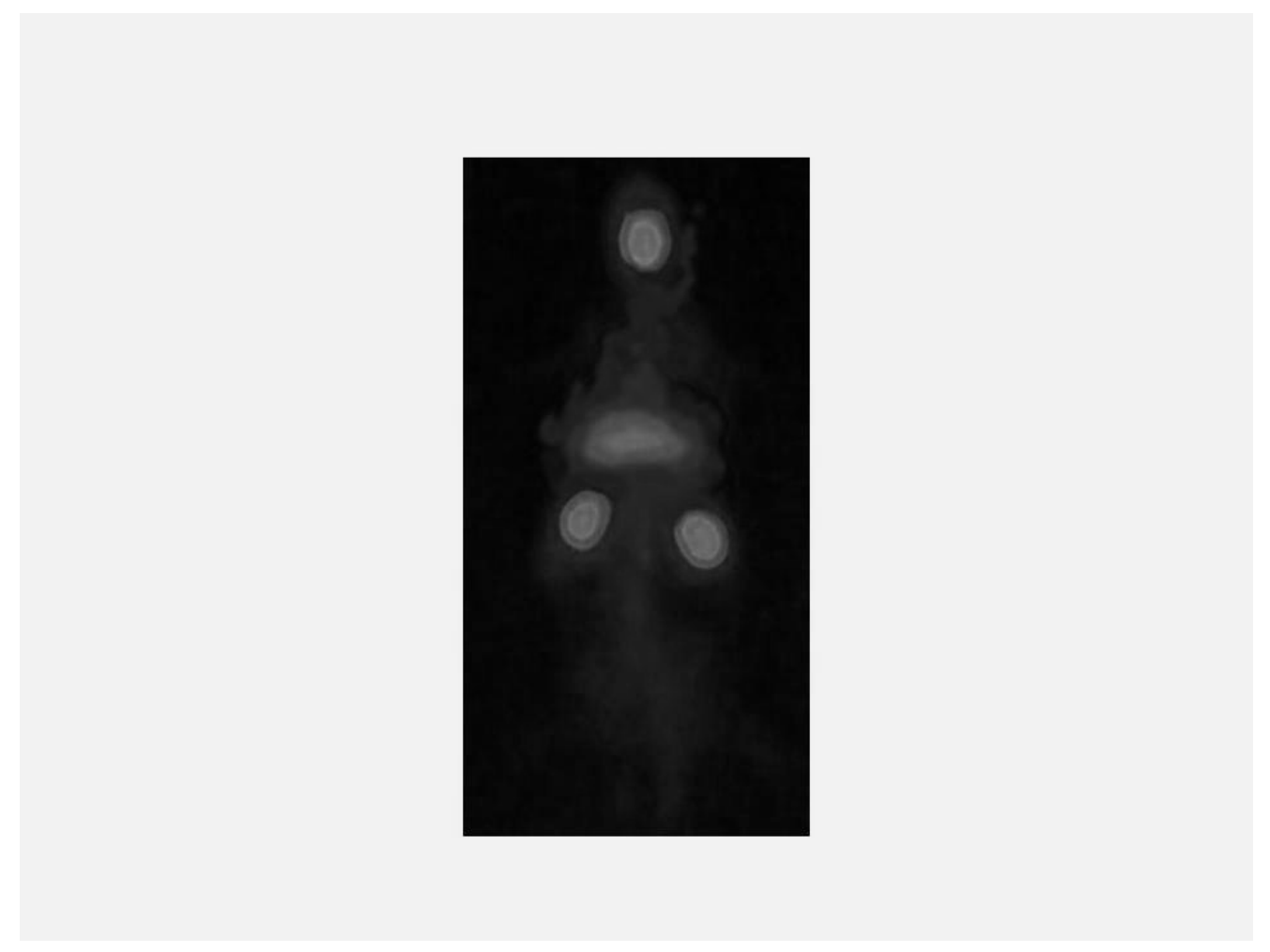

Figure 4 - YAP(S)PET image of the biodistribution of the complex $\left[{ }^{99 m}{ }^{\mathrm{Tc}}\left(\mathrm{NBEt}_{3}\right)(\mathrm{PS})\right]$ $\left\{\mathrm{PS}=\left[\mathrm{CH}_{3}\left(\mathrm{CH}_{2}\right)_{2}\right]_{2}-\mathrm{P}\left(\mathrm{CH}_{2}\right)_{2} \mathrm{SH}\right\}$ in a rat at 1 hour post injection

Although at present the mechanism of brain localization of these new complexes remains still undetermined, it is relevant to note that the affinity of boron compounds for the nervous tissue has been previously observed in applications related with boron neutron capture therapy (Miyatake et al., 2007).

At present, the most critical problem with this new class of borane-nitrido Tc-99m derivatives lies in the reaction procedure utilized for their preparation that does not appear to furnish a satisfactory yield of formation. In addition, it was found that preparations carried out in the presence of trace amount of water did not allow the production of this new type of Tc-99m complexes. Further studies are required to evaluate the potential applicability of $\left[{ }^{99 \mathrm{~m}} \mathrm{Tc}\left(\mathrm{NBEt}_{3}\right)(\mathrm{PS})_{2}\right]$ complexes to the production of useful radiopharmaceuticals.

\section{RESUMO}

Uma nova classe de complexos de Tc-99m capazes de atravessar a barreira hemato-encefálica foi investigada e descrita neste trabalho. Estes compostos são formados reagindo os precursores bissubstituídos do nitrido $\left[{ }^{99 \mathrm{~m}} \mathrm{Tc}(\mathrm{N})(\mathrm{PS})_{2}\right] \quad(\mathrm{PS}=$ phosphino-tiol ligante) com trietillborano $\left(\mathrm{BEt}_{3}\right)$ sob restritas condições anidras e usando solventes não aquosos. A estrutura molecular desses traçadores não foi totalmente estabelecida, mas evidências experimentais preliminares sugerem que eles resultam da interação da base de Lewis $\left[{ }^{99 \mathrm{~m}} \mathrm{Tc}(\mathrm{N})(\mathrm{PS})_{2}\right]$ com o ácido de Lewis $\mathrm{BEt}_{3}$, le-

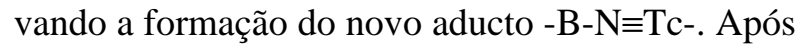
purificação e recuperação em uma solução fisiológica, os novos derivados borano-nitrido-Tc-99m foram injetados em ratos para avaliação de seu comportamento biológico in vivo. Os resultados mostraram uma acumulação significativa no tecido cerebral, indicando que estes complexos são capazes de atravessar a barreira hemato-encefálica íntegra. A captação pelo sistema nervosa central foi confirmada pela imagem da distribuição de ativi- 
dade em animais vivos, usando um scanner para animais pequenos (YAP(S)SPECT).

\section{REFERENCES}

Bolzati, C., Boschi, A., Uccelli, L., Malago, E., Bandoli, G., Tisato, F., Refosco, F., Pasqualini, R., Duatti, A. (1999), Synthesis of a novel class of trigonal bipyramidal nitrido $\mathrm{Tc}(\mathrm{V})$ complexes with phosphinothiol ligands. crystal structure of $\left[\left(^{99 \mathrm{~g}}\right) \mathrm{Tc}(\mathrm{N})(\mathrm{L}(1))(2)\right]$ $[\mathrm{L}(1)=2$-(diphenylphosphino)ethanethiolato $]$ and $\left.\left[{ }^{99 \mathrm{~g}}\right) \operatorname{Tc}(\mathrm{N})(\mathrm{L}(5))(2)\right] \quad[\mathrm{L}(5) \quad=2-$ (ditolylphosphino)propanethiolato]. Inorg. Chem., 38, 4473-4479.

Boschi A, Uccelli L, Bolzati C, Duatti A, Sabba N, Moretti E, Di Domenico G, Zavattini G, Refosco F, Giganti M. (2003), Synthesis and biological evaluation of monocationic asymmetric 99mTc-nitride heterocomplexes showing high heart uptake and improved imaging properties. J. Nucl. Med., 44, 806814.

Boschi, A., Duatti, A., Uccelli, L. (2005), Development of technetium-99m and rhenium-188 radiopharmaceuticals containing a terminal metal-nitrido multiple bond for diagnosis and therapy. Top. Curr. Chem., 252, 85-101.
Di Domenico, G., Zavattini, G., Moretti, E., Piffanelli, A., Giganti, M., Motta, A., Sabba, N., Uccelli, L., Benini, E., Duatti, A., Bolzati, C., Boschi, A., Del Guerra, A. (2003), YAP-(S)PET small animal scanner: first quantitative results. IEEE Trans. Nucl. Sci., 50, 1351-1356.

Duatti, A., Boschi, A., Ucelli, L. (2002), Technetium-99m nitrido radiopharmaceuticals with unprecedented biological properties. Braz. Arch. Biol. Tech. 45, 135-142.

Johannsen, B., Pietzsch, H. J. (2002), Development of technetium-99m-based CNS receptor ligands: have there been any advances? Eur. J. Nucl. Med. Mol. Imaging, 29, 263-275.

Kung, H. F. (2001), Development of Tc-99m labeled tropanes: TRODAT-1, as a dopamine transporter imaging agent. Nucl. Med. Biol. 28, 505-508.

Humm, J. L., Rosenfeld, A., Del Guerra, A. (2003), From PET detectors to PET scanners. Eur. J. Nucl. Med. Mol. Imaging, 30, 1574-1597.

Miyatake, S., Tamura Y, Kawabata S, Iida K, Kuroiwa T, Ono K. (2007), Boron neutron capture therapy for malignant tumors related to meningiomas. Neurosurgery, 61, 82-90. 